Article

\title{
International Trade in Transport Services between Poland and the European Union
}

\author{
Agnieszka Malkowska ${ }^{1, *(1)}$ and Arkadiusz Malkowski ${ }^{2}$ \\ 1 Institute of Management, University of Szczecin, Cukrowa 8, 71-004 Szczecin, Poland \\ 2 Faculty of Economics, West Pomeranian University of Technology Szczecin, 71-270 Szczecin, Poland; \\ amalkowski@zut.edu.pl \\ * Correspondence: agnieszka.malkowska@usz.edu.pl
}

Citation: Malkowska, A.; Malkowski, A. International Trade in Transport Services between Poland and the European Union. Sustainability 2021, 13, 424. https://doi.org/10.3390/ su13010424

Received: 29 November 2020 Accepted: 30 December 2020 Published: 5 January 2021

Publisher's Note: MDPI stays neutral with regard to jurisdictional clai$\mathrm{ms}$ in published maps and institutional affiliations.

Copyright: (C) 2021 by the authors. Licensee MDPI, Basel, Switzerland. This article is an open access article distributed under the terms and conditions of the Creative Commons Attribution (CC BY) license (https:// creativecommons.org/licenses/by/ $4.0 /)$.

\begin{abstract}
The structure of international trade in today's global economy is undergoing transformation. The increase in the importance of services is a clear trend. In Polish foreign trade with the European Union countries, it is transport services that to the greatest extent create the trade surplus. These services significantly affect the environment, which makes it necessary to take measures aimed at the implementation of the green transport principles. The aim of the study was to provide a detailed description of transport services in Polish foreign trade with European Union (EU) countries and to assess the role of these services in Polish economy, including in terms of sustainable development. The study concerned transport services, consisting of four separate types: maritime transport, air transport, other transport services (except maritime and air) and postal and courier services. The time span of the study was 2010-2018. The latest secondary data from the official statistics of the National Bank of Poland and the Central Statistical Office were used for the purpose of the analysis. The research methods included: critical analysis of the source literature, analysis of secondary data (deskresearch) and graphic methods (tables and diagrams), by means of which the results of the study were presented. The conclusions drawn are inductive and deductive in nature. The article describes in detail Polish trade in transport services with EU countries. It focuses on export, import and balance. The role of the examined services in foreign trade and Polish economy was assessed based on the analysis of the structure of export and import and the rate of export and import, geographical orientation of trade, as well as the activity of enterprises from the transport service sector, registered in Poland, including joint ventures. Research has shown that between 2010 and 2018 Polish export and import of transport services as part of trade relations with EU countries increased considerably. The conducted research indicates that transport services are a crucial element of Polish trade. The role of EU countries in the Polish trade in transport services was recognised as significant and growing. This has a positive impact on the country's economy. The increasing role of road transport in the structure of the Polish trade indicates that Polish entities providing transport services are thriving in this demanding market. However, the analysis of the source literature indicated changes in the preferences of consumers, who increasingly often expect the implementation of sustainable development principles in the distribution of goods. Green marketing or green transport are concepts more and more frequently used to gain competitive advantage in the market. The transport sector in Poland is facing a major trend towards the implementation of sustainable development principles. In order to maintain sales growth internationally, the entities will have to implement sustainable development principles.
\end{abstract}

Keywords: foreign trade; international trade; transport services; sustainable development; economic development

\section{Introduction}

According to Siche, et al., the role of ecological economics is to provide the necessary knowledge of the links between the economic and ecological systems. This is intended 
to help implement the principles of sustainable development. Providing knowledge of sustainable management is one of the directions in modern economic research into economic development [1].

Foreign trade continues to be considered as one of the main driving forces of the economic development of countries. The benefits of this fastest growing economic activity are significant not only for weak and developing economies, but also for the developed ones [2]. It should be stressed that international trade is justified not only by issues related to economy, climate or raw materials, but also, more importantly today, by aspects related to the pursuit of sustainable development $[3,4]$. A significant feature of international trade is its changing structure. Since the mid-20th century, the importance of services has been growing $[5,6]$. This is mainly manifested by flourishing international trade and the share of services in GDP. These trends are also observed in Poland. The causes and effects of these correlations should therefore be identified in order to better understand modern economics and sustainable transport economics.

The aim of the study was to provide a detailed description of transport services in Polish foreign trade with European Union (EU) countries and to assess the role of these services in Polish economy, including in terms of sustainable development. The findings of this research can be useful in developing a long-term strategy to support the sustainable development of the transport services sector in Poland and the EU.

The studies carried out indicate the importance of transport services in Poland's foreign trade. In 2018, Polish companies transported almost 270 million tonnes of freight, representing $23 \%$ of the EU road freight. Poland is an undisputed leader in the delivery of transport services in Europe [7]. The volume of road transport in the period under consideration has increased almost continuously since Poland joined the EU. Since 2004, the volume of freight carried by Polish companies has increased more than six times. Since 2006, transport performance measured in tonne-kilometres carried out by Polish transport companies in international transport has been higher than transport performance attained in the domestic market. In 2018, international transport already accounted for $64 \%$ of Polish companies' overall transported freight [7].

The development of trade was affected not only by factors of a global nature (e.g., liberalisation of international trade in services on the World Trade Organization Forum). The fact that Poland became a member of the European Union in 2004, which provided access to the European Single Market, should be considered as the main determinant. Polish trade in foreign services is not only an interesting research problem but is also important with regard to the sustainable development of the country.

Between 2010 and 2018, the export of services more than doubled, while the export of goods increased by approximately $80 \%$. In addition, during that period, Poland always had a trade surplus and its balance had grown steadily, which was not the case with the trade in goods [8]. Thus, foreign trade in services has been one of the drivers of Poland's high economic growth in recent years. In 2018, the total value of exports and imports of services represented nearly $20 \%$ of GDP. Transport services were the most significant contributor to the positive balance of trade in services over the period 2010-2018.

At the same time, the analyses carried out showed that the year 2018 saw the first decrease in international transport operations by Polish carriers in 15 years. Given the volume of freight, the transport operations by Polish carriers decreased by $6.4 \%$ compared to 2017. According to transport company manager, the competitiveness of Polish transport companies can be improved by implementing the principles of sustainable development. The development of the concept of sustainable growth, including new transport technologies, is increasingly contributing to offshoring services, which benefits countries with lower labour costs. It is important, however, that at the same time high standards of conservation of the environment are maintained. The development of the transport sector in Poland was accompanied by dynamic changes related to the implementation of the concept of sustainable development, and, above all, green transport [9]. This, combined with the trends in the transport market in Europe, has improved the competitiveness of regional 
and international transport service providers [10]. It has a positive impact on the social and economic development of Poland which is reflected in the sector's increasing share in Polish GDP.

\section{Literature Overview}

Rapid economic growth on a global scale, observed since the end of the Second World War, is the result of political, economic, social and cultural changes that contributed to the development of globalisation [11,12]. According to Ritzer and Malone, and Harsch, the widespread consumerist lifestyle as well as the imitation or standardisation of demand patterns today provide unlimited opportunities for commercial expansion $[13,14]$. As indicated by Atkinson, the intensification of international trade and political integration between countries has led to changes in economic doctrines in many countries [15]. The post-Keynesian statism has been gradually replaced by pro-market doctrines, rooted in supply-side economics with an emphasis on cost reduction, efficiency and competition [16].

The traditional dominance of Western European countries, the United States and Japan has been shaken. The works of Baldwin and others indicate that new countries have emerged, including those from the Central and Eastern Europe, which are occupying more and more prominent role in the world trade, creating new trade flows $[17,18]$. In particular, this applies to the phenomenon of offshoring services, which is analysed in depth by Roza et al. and Head et al. $[19,20]$. As a result, recent decades have seen a sharp decline in the importance of traditional inter-industry trade and an increasing share of intra-industry trade with a growing significance of services [21,22]. However, so far, the theoretical considerations have not led to the creation of a universal theory of international trade in services corresponding to the current reality. Contributory works clearly indicate the growing importance of services in the process of globalisation of the modern economy. It is worth pointing out in this respect to studies emphasising the complementary relationship between the export of goods and the import of services [19,23]. Additionally, there is growing interest in analysing the impact of innovative services on the development of international trade [24,25]. There are attempts to formulate universal demand concepts which relate to the phenomenon of expanding international trade in goods and services. This is confirmed by the increasingly popular concepts based on the S. Burenstam-Linder preference similarity theory.

Today, the traditional international division of labour, created on the basis of the complementarity of countries in terms of abundance and availability of natural resources, has evolved into a global division of labour defined primarily by capital, services and innovation. The creation of a modern (global) division of labour has been accompanied by a growing importance of the qualifications of the labour force, its mobility, as well as higher expenditure on research and, as a result, a greater role of international competitiveness in the process of opening economies. According to Ritzer and Esmer, the progressive globalisation leads to a "McDonaldization" of modern economies, creating similar consumption patterns $[14,26]$. This entails a number of social and environmental risks associated with the development of international trade. The direct external costs of the development of transport services in the international trade include, inter alia [27,28]:

- $\quad$ pollution of the environment;

- adverse impact on climate and landscape;

- time consumption and traffic congestion;

- noise.

Heavy goods vehicles together with other fleet vehicles and buses are responsible for $\frac{1}{4}$ of $\mathrm{CO}_{2}$ emissions in the European Union [29]. In an era of globalisation and growing consumption, the need for international and regional supplies of goods will increase. This entails more transports and higher pollutant emissions. In order to address this problem, a number of measures under the sustainable social and economic development policy are being introduced. This is accompanied by the implementation of increasingly stringent standards in transport services, leading to a reduction in external transport costs. However, 
this results in additional costs associated with the provision of necessary infrastructure, purchasing modern means of transport, etc. Nevertheless, it should not reduce mobility, but enable finding a compromise between environmental and economic objectives. Meeting rigorous EURO emission standards is one of the main challenges for the transport market. New technologies open up new opportunities. Not only can vehicles become greener, but also the whole transport sector should be more efficient and thus have less environmental impact. This will allow further development of international trade without harming the environment.

One of the concepts affecting the demand for products and services on a global scale emphasises abiding by the sustainable development principles $[4,30]$. The concept of sustainable development pays great attention to the problems of the adverse environmental impact of business and to the socio-economic consequences of environmental degradation [31,32]. The main challenge within this concept is to balance economic, social and environmental elements, while one of the conditions for achieving a favourable balance is to promote the environmental awareness of the society. Discussions on the definition and scope of sustainable development have led to the development of a number of guidelines for its implementation. The following have been considered necessary and key actions [33]:

- comprehensive and long-term planning of socio-economic development accounting for the productive and non-productive functions of the environment;

- accounting for and anticipating the environmental impact of human economic activities;

- accounting for feedback in both ecology and economics, on the one hand, and at the interface between the two areas, on the other;

- accounting for and measuring tangible and intangible assets and features of the environment;

- accounting for the qualitative changes taking place in the environment, including in particular irreversible changes;

- accounting for and implementing development models which will not conflict with the factors in such development, including in particular environmental conditions, substitution between factors of production, and technical and technological progress.

The development of transport, on the one hand, is the basis for the economic development of regions and their improved competitiveness, and on the other hand, it contributes to environmental degradation [34,35]. Some transport companies account for this problem in their development strategies and specify precisely targeted long-term measures that can be classified as good practices in the area concerned [36].

The so-called eco-marketing, also referred to as green marketing, is a special example of the above solutions. It is a type of marketing activity in which attitudes and behaviours oriented towards environmental protection are simultaneously promoted. Green marketing may take various forms and may involve environmentally friendly activities of both the customer and the manufacturer [37]. Green marketing activities are focused on the product, its packaging, the method of production, and - more and more often — distribution [38,39]. In green marketing, environmental criteria are taken into account when planning the means of transport, the distance needed to transport raw materials or finished products, or when sourcing suppliers. This concept promotes a responsible approach to sustainable development by selecting those transport services which contribute to the reduction of the harmful emissions associated with the use of means of transport.

The analysis of the literature indicates that the competitiveness of transport services is influenced by many factors, among others: geographical location, innovativeness of applied technical and organisational solutions, quality of infrastructure, level of technical advancement of means of transport, as well as implementation of sustainable development principles in the activities of transport service providers [40,41]. The solution to these challenges is the concept of green transport, discussed in the literature, as a new concept of gaining regional and international competitiveness [9,42]. This concept promotes new, environmentally friendly technological and organisational solutions adopted in transport 
services [10,43]. Green transport is defined as the need to maintain a balance between economic, social and natural factors $[9,10,40]$. The concept of sustainable transport is often becoming part of the corporate social responsibility (CSR) strategy of numerous entities building their competitiveness [44,45]. We are dealing with a permanent process, affecting all spheres of economic life, including global trade. This leads to radical changes in the functioning of the world economy, creating a new quality, which is based on the growing importance of the concept of sustainable development in the creation of global demand preferences which characterise societies at large [46]. It has a significant impact on the operation and development of the transport sector at regional and international level. It leads to increased trade between countries, the diffusion of knowledge and innovation and, above all, to greater awareness of the need to balance economic and environmental objectives. This results in the emergence of an entire system which develops international relations between consumers and producers. It is based on high-quality, sustainable transport services. This is all the more important as the transport sector is a major source of income for many economies. In Europe, the transport sector accounts for about $5 \%$ of gross domestic product (GDP) and more than 10 million people are directly employed in 1.1 million transport companies [47]. It is taking place at the expense of the environment and becoming a significant factor of regional growth. As the transport sector serves a crucial role regionally and internationally, it is necessary to undertake theoretical and practical research on the main problems and trends observed in this area of the economy.

\section{Materials and Methods}

The article addresses the issue of international trade in services. The analyses contained herein should be seen as a case study. The results presented are part of a broader investigation into the determinants of the competitiveness of the international transport services provided by Polish carriers. Research into this subject is conducted by the West Pomeranian University of Technology in Szczecin and the University of Szczecin, Poland. The research as presented herein focuses on Poland's foreign trade. The emphasis is put exclusively on trade with the member states of the European Union, which Poland joined in 2004. The data were collected between 2017 and 2019 using various methods, including a review of the literature, public documents and statistics, and interviews with transport industry representatives.

The data obtained allowed the use of quantitative methods such as structure ratios, dynamics indices, the ratio of exports of transport services to EU member States to the Polish GDP, and the ratio of imports of transport services from EU member States to the Polish GDP.

The related data are derived from the public statistics of the National Bank of Poland (NBP). They comply with international standards, such as: Balance of Payments and International Investment Position Manual Sixth Edition (BPM6) and Manual on Statistics of International Trade in Services 2010 (MSITS 2010). Moreover, the statistical data used in the research are consistent with the published data on national balance of payments. This source of information was also selected due to the fact that these statistics provide detailed classification of services and the geographical orientation of their trade flows.

The aim of the study was to provide a detailed description of transport services in Polish foreign trade with EU countries and to assess the role of these services in Polish economy, including in terms of sustainable development.

The growing share of transport services in Polish foreign trade and the growing scale of external costs of transport point to the need for the Polish government to take strategic measures to implement technical and organisational solutions aimed to reduce the negative environmental impact of the developing sector. In order to achieve this objective, elements of the management case study (MCS) method were used, as this approach allows the use of a wide range of techniques and tools for data acquisition and analysis [48,49]. By way of a detailed internal empirical case study, the causal mechanisms can be identified. This enables generalised causal mechanisms to be identified and used in order to link the causes 
and their effects [50]. A survey was used to improve the knowledge derived from the research. The survey was carried out among 25 transport sector managers. A standardised survey questionnaire and the paper and pencil interview method were used.

The following hypotheses were formulated in the study preparation phase:

- Poland's dominant position in EU road transport is the result of growing trade flows, liberalised access to the EU transport services market, and the high competitiveness of Polish companies.

- The increasing consumer awareness requires transport solutions that are more environmentally friendly.

In the first stage of the research process, the current state of knowledge on foreign trade, the concept of sustainable development, especially concerning the trade in services, was assessed. The theoretical part was based on the analysis of available source literature on international trade, transport economics and economic development. In it, the idea of sustainable transport as an alternative to traditional forms of transport is presented.

The subsequent section provides an overview of Poland's foreign trade with European Union countries in the field of international trade in transport services. The authors sought to adopt a comprehensive approach (i.e., including export of services, import of services and balance). The analyses carried out cover the years 2010-2018. The overview of Polish foreign trade in transport services with EU countries was further supplemented by the analysis of four types of services included in the examined component. It includes revenues from foreign sales of individual services as well as expenditures. In addition, the structure of different types of services which form the transport service component is presented.

In the last section of the paper conclusions of the research are presented. They were drawn on the basis of a critical analysis of the source literature and an analysis of secondary data (desk-research), which allowed reaching inductive and deductive conclusions. Certain research results are presented in tables and diagrams. The research limitations included the temporal scope, which was dictated by the availability of foreign trade data for Poland. Such data have been published by the NBP since 2010. Another limitation concerned the interpretation of the results of qualitative studies based on responses from the respondents. The respondents represented specific needs, values and expectations that had a significant impact on their responses.

\section{Polish Foreign Trade in Transport Services with European Union Countries in 2010-2018}

\subsection{General Overview}

The role of transport services in Polish foreign trade with European Union countries is still growing. The years 2010-2018 saw a systematic increase in both exports of services, imports of services and trade balances. The value of transport services provided by Poland to EU markets increased from EUR 4.8 billion in 2010 to EUR 13.4 billion in 2018 (see Figure 1). This means that the export of transport services to the EU increased 2.8 times, while in the same period Poland's total export of transport services only increased 2.6 times. The highest revenues for the Polish economy were generated by foreign sales to the EU market of so-called other transport services (almost EUR 4.3 billion in 2010 and EUR 11.9 billion in 2018).

In 2010, Polish imports of transport services from EU countries reached the level of EUR 3.3 billion, and in 2018 already EUR 6.4 billion (see Figure 1). Thus, an increase of more than 1.9 times was recorded and it was minimally smaller than the total Polish import of transport services, which increased 2 times. The highest expenditure was incurred for the acquisition of so-called other transport services in EU countries (EUR 2.2 billion in 2010 and EUR 4.2 billion in 2018) (see Table 1). Thus, in Polish foreign trade in transport services with EU countries the export growth rate was much higher than that of imports. 


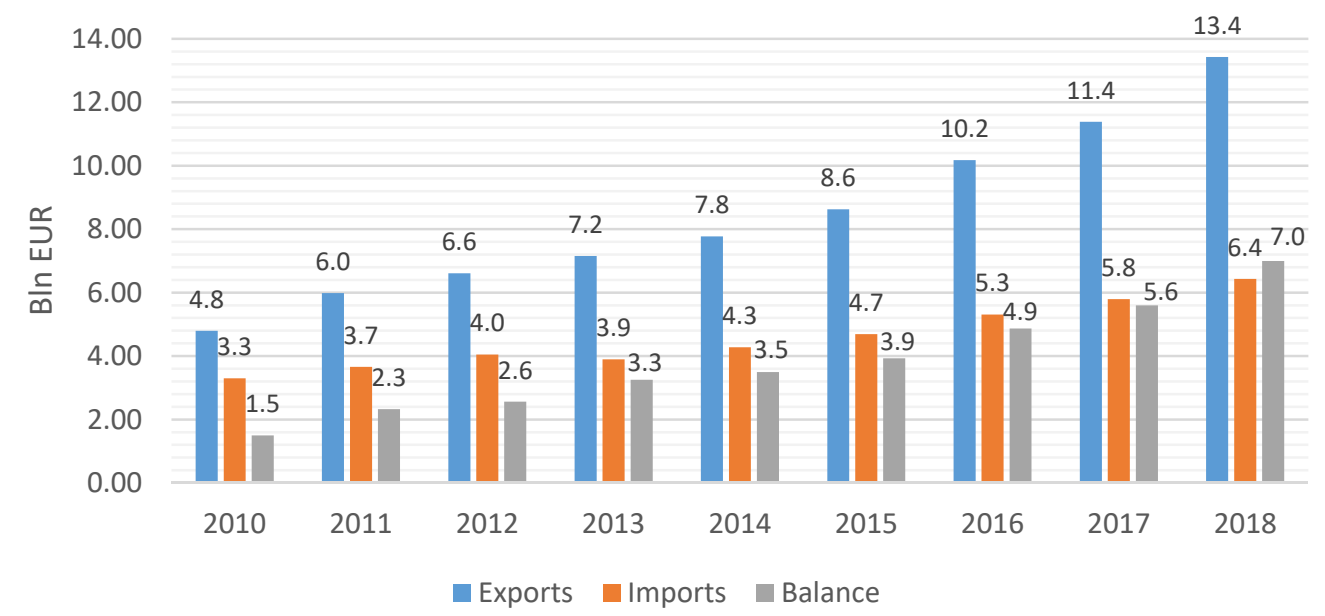

Figure 1. The exports, imports and balance of trade in transport services in Poland between 2010 and 2018 (in billion EUR). Source: Compiled by the authors based on [51].

Table 1. Poland's trade with EU member states by the main components of transport Scheme 2010. and 2018 (billion EUR; \%). Source: Compiled by the authors based on [51].

\begin{tabular}{|c|c|c|c|c|c|c|}
\hline \multirow{2}{*}{ Service } & \multicolumn{3}{|c|}{2010} & \multicolumn{3}{|c|}{2018} \\
\hline & Exports & Imports & Balance & Exports & Imports & Balance \\
\hline Maritime transport & $\begin{array}{c}0.16 \\
(3.2 \%)\end{array}$ & $\begin{array}{c}0.59 \\
(18.0 \%)\end{array}$ & -0.44 & $\begin{array}{c}0.32 \\
(2.4 \%)\end{array}$ & $\begin{array}{c}0.95 \\
(14.7 \%)\end{array}$ & -0.63 \\
\hline Air transport & $\begin{array}{c}0.32 \\
(6.6 \%)\end{array}$ & $\begin{array}{c}0.39 \\
(11.8 \%)\end{array}$ & -0.07 & $\begin{array}{c}1.07 \\
(7.9 \%)\end{array}$ & $\begin{array}{c}1.06 \\
(16.5 \%)\end{array}$ & 0.01 \\
\hline $\begin{array}{c}\text { Other transport services (except } \\
\text { maritime and air) }\end{array}$ & $\begin{array}{c}4.27 \\
(89.0 \%) \\
\end{array}$ & $\begin{array}{c}2.24 \\
(68.0 \%) \\
\end{array}$ & 2.02 & $\begin{array}{c}11.86 \\
(88.3 \%)\end{array}$ & $\begin{array}{c}4.19 \\
(65.2 \%)\end{array}$ & 7.66 \\
\hline Postal and courier services & $\begin{array}{c}0.06 \\
(1.2 \%)\end{array}$ & $\begin{array}{c}0.07 \\
(2.2 \%)\end{array}$ & -0.02 & $\begin{array}{c}0.19 \\
(1.4 \%)\end{array}$ & $\begin{array}{c}0.23 \\
(3.5 \%)\end{array}$ & -0.04 \\
\hline Transport services-total & $\begin{array}{c}4.80 \\
(100 \%)\end{array}$ & $\begin{array}{c}3.30 \\
(100 \%)\end{array}$ & 1.50 & $\begin{array}{c}13,43 \\
(100 \%)\end{array}$ & $\begin{array}{c}6.43 \\
(100 \%)\end{array}$ & 7.00 \\
\hline
\end{tabular}

It should be noted that during the examined nine-year period, the trade balance of transport services has always been positive. It increased from EUR 1.5 billion in 2010 to PLN 7.0 billion in 2018. Considerably faster growth in exports of services than that in imports has resulted in a significant increase in the trade surplus in these services. Therefore, the Polish balance of international trade in transport services with EU countries increased 4.6 times, while the total balance of such services increased only 4.2 times. In conclusion, Poland has had a sustained surplus of exports of transport services over imports.

\subsection{The Structure of Polish Foreign Trade in Transport Services with EU Countries}

The Polish foreign trade in transport services with EU countries was dominated by "Other transport services (except maritime and air)", which includes road transport. In recent years, road transport in Poland has undergone significant changes. This was related to the obligation to purchase new vehicles which meet increasingly stringent emission standards. As a result, new EURO 6 vehicles generate 98\% less NO2 than the Euro 0 standard vehicles. This allows Polish entities to freely provide transport services in all European countries. This undoubtedly contributed to the significant increase in the share of road transport in Polish foreign trade observed in the analysed period. In 2018, transport services accounted for as much as $88.3 \%$ of exports to the EU. Air transport $(7.9 \%)$ and maritime transport (2.4\%) represented a smaller share. The smallest share was recorded for postal and courier services (1.2\%). The structure of import of the examined services is 
different. Other transport services accounted for $65.2 \%$ in the target year. The share of air and maritime transport was fairly similar and amounted to $16.5 \%$ and $14.7 \%$, respectively. The smallest share in the structure of import of transport services was represented by postal and courier services, at 3.5\% (Table 1).

Moreover, it should be stressed that in the years 2010-2018 the structure of Polish foreign trade in transport services with EU countries underwent changes. In the case of exports, the share of air transport and postal and courier services increased slightly (by 1.3 percentage points and 0.2 percentage points respectively), whereas the share of maritime transport and other transport services decreased (by 0.9 percentage points and 0.7 percentage points respectively). The share of imports changed more significantly. The increase concerned the share of air transport (by 4.7 percentage points) and postal and courier services (by 1.3 percentage points). The share of the market was reduced in respect of maritime transport (by 3.3 percentage points), as well as in the group of other transport services (by 2.8 percentage points) (Table 1 ).

In 2018, compared to 2010, there was an increase in both exports and imports of all types of transport services. The highest increase was recorded in postal and courier services (by $236 \%$ in exports and by $210 \%$ in imports) and air transport (by $234 \%$ in exports and by $174 \%$ in imports).

The Member States of the European Union are among Poland's main trading partners, particularly in the case of transport services. In the analysed period, the share of the EU in revenues from foreign sales of transport services rose from $76.1 \%$ in 2010 to $81.9 \%$ in 2018. In the case of expenditures on acquisition of the analysed services on the EU markets, a minimal decrease was recorded (i.e., from $74.2 \%$ in 2010 to $74.1 \%$ in 2018) (Table 2). The share of EU countries is therefore significant in the Polish trade in transport services and represents more than four fifths for exports and almost three fourths for imports.

Table 2. The share of Poland's trade with EU member states in transport services in the country's overall international trade in transport services. Source: Compiled by the authors based on [51].

\begin{tabular}{|c|c|c|c|c|}
\hline \multirow{2}{*}{ Service } & \multicolumn{2}{|c|}{2010} & \multicolumn{2}{|c|}{2018} \\
\hline & Exports & Imports & Exports & Imports \\
\hline $\begin{array}{l}\text { Transport services-total } \\
\text { Including: }\end{array}$ & 76.1 & 74.2 & 81.9 & 74.1 \\
\hline Maritime transport & 61.0 & 76.0 & 67.0 & 70.7 \\
\hline Air transport & 48.7 & 61.6 & 52.4 & 65.2 \\
\hline $\begin{array}{c}\text { Other transport services (except } \\
\text { maritime and air) }\end{array}$ & 80.1 & 76.1 & 86.9 & 76.9 \\
\hline Postal and courier services & 88.4 & 90.9 & 76.9 & 90.6 \\
\hline
\end{tabular}

Additionally, the analysis of individual types of services, which are categorised as transport services, revealed that the importance of EU markets for the Polish economy is increasing. Between 2010 and 2018, the share of all types of services except for postal and courier services increased in exports. However, the share of imports has declined only in the case of maritime transport.

In 2018, the share of revenues from the export of services to the EU ranged from $52.4 \%$ for air transport to $86.9 \%$ for other transport services. In imports, that share was between $65.2 \%$ for air transport and $90.6 \%$ for postal and courier services (Table 2).

\subsection{Exports, Imports and Trade Balance of Transport Services by EU Country}

An analysis of the trade in services has indicated that between 2010 and 2018 Poland has established trade relations in respect of transport services with all the then Member States of the European Union. However, the significance of this cooperation, measured in terms of export and import volumes, was quite diverse (Table 3). The largest share of revenue from the sale of foreign transport services in 2010 was generated by such countries as Germany $(25.8 \%)$, the Netherlands $(8.2 \%)$, France $(6.4 \%)$, the United Kingdom $(5.2 \%)$ and 
Belgium (4.1\%). In 2018, this share was generated by Germany (25.9\%), the Netherlands $(10.2 \%)$, France (5.7\%), Sweden (5.1\%) and the United Kingdom (4.7\%). As may be observed, over the nine years, the main partner for Poland in the export of transport services was still Germany. The Netherlands and Sweden increased their share, whereas that of Belgium, France and the United Kingdom decreased. The least important as regards the export of transport services for Poland were Croatia $(0.03 \%)$ and Slovenia $(0.08 \%)$ in 2010, and Malta $(0.09 \%)$ and Croatia $(0.14 \%)$ in 2018. The highest export growth rate was recorded in Luxembourg (almost $1100 \%$ ), which may be explained by the fact that many companies are registered and based there. This was followed by a significant increase in Croatia (by 860\%), as well as Slovenia (by 490\%), Sweden (by $458 \%$ ) and Estonia (by $423 \%$ ).

Table 3. Poland's UE trade partners in the exports and imports of transport services in 2010 and 2018 (million EUR, \%). Source: Compiled by the authors based on [51].

\begin{tabular}{|c|c|c|c|c|c|c|c|c|}
\hline & \multicolumn{4}{|c|}{ Exports } & \multicolumn{2}{|c|}{ Imports } & \multicolumn{2}{|c|}{ Balance } \\
\hline & 2010 & 2018 & $\begin{array}{c}2018 / 2010 \\
\%\end{array}$ & 2010 & 2018 & $\begin{array}{c}2018 / 2010 \\
\%\end{array}$ & 2010 & 2018 \\
\hline Austria & 243 & 580 & 138 & 161 & 298 & 86 & 83 & 281 \\
\hline Belgium & 259 & 431 & 66 & 199 & 277 & 39 & 60 & 154 \\
\hline Bulgaria & 8 & 37 & 397 & 27 & 80 & 197 & -20 & -43 \\
\hline Croatia & 2 & 23 & 860 & 4 & 20 & 453 & -1 & 3 \\
\hline Cyprus & 35 & 47 & 35 & 90 & 117 & 30 & -56 & -71 \\
\hline Denmark & 184 & 560 & 205 & 190 & 350 & 84 & -7 & 211 \\
\hline Estonia & 10 & 54 & 423 & 6 & 88 & 1331 & 4 & -34 \\
\hline Finland & 47 & 165 & 252 & 32 & 59 & 85 & 15 & 105 \\
\hline France & 404 & 942 & 133 & 151 & 328 & 118 & 253 & 614 \\
\hline Greece & 15 & 48 & 232 & 15 & 36 & 140 & 0 & 13 \\
\hline Spain & 120 & 339 & 182 & 69 & 155 & 123 & 51 & 184 \\
\hline Ireland & 76 & 162 & 114 & 16 & 115 & 610 & 59 & 46 \\
\hline Lithuania & 50 & 187 & 276 & 54 & 157 & 192 & -4 & 29 \\
\hline Luxembourg & 52 & 618 & 1078 & 41 & 70 & 70 & 11 & 548 \\
\hline Latvia & 12 & 52 & 333 & 12 & 30 & 142 & -1 & 22 \\
\hline Malta & 10 & 15 & 56 & 15 & 21 & 42 & -5 & -7 \\
\hline Netherlands & 516 & 1645 & 219 & 248 & 611 & 146 & 268 & 1034 \\
\hline Germany & 1623 & 4254 & 162 & 1079 & 1832 & 70 & 544 & 2422 \\
\hline Portugal & 12 & 35 & 192 & 8 & 33 & 286 & 3 & 2 \\
\hline Czech Rep. & 208 & 477 & 130 & 217 & 270 & 24 & -9 & 208 \\
\hline Romania & 43 & 154 & 257 & 20 & 147 & 618 & 23 & 6 \\
\hline Slovakia & 76 & 235 & 208 & 75 & 136 & 83 & 1 & 98 \\
\hline Slovenia & 5 & 29 & 490 & 10 & 38 & 298 & -5 & -9 \\
\hline Sweden & 151 & 841 & 458 & 108 & 278 & 157 & 42 & 562 \\
\hline Hungary & 75 & 195 & 158 & 46 & 153 & 229 & 29 & 42 \\
\hline UK & 330 & 776 & 135 & 246 & 452 & 84 & 84 & 324 \\
\hline Italy & 230 & 523 & 127 & 156 & 276 & 77 & 74 & 248 \\
\hline
\end{tabular}

In 2010, the most important group of importers of transport services were such countries as: Germany (24.3\%), the Netherlands (5.8\%), the United Kingdom (5.5\%), the Czech Republic (4.9\%) and Belgium (4.5\%). In 2018 these countries included: Germany $(21.1 \%)$, the Netherlands (7.0\%), the United Kingdom (5.2\%), Denmark (4.0\%) and France (3.8\%). The most spectacular increase in imports of transport services to Poland was recorded in Estonia (by more than 1300\%), as well as Romania (by 618\%) and Ireland (by 610\%). In the base year (2010), Poland recorded a trade deficit in transport services 
with nine EU countries and only with five in the target year (2018). In 2010, Germany, the Netherlands and France had contributed to the greatest extent to Poland's trade surplus in the examined data.

In 2018, these countries again included Germany and the Netherlands, but also France, Sweden and Luxembourg. To sum up, trade in transport services with affluent Western European countries was the most significant determinant of Poland's trade surplus. Additionally, markets in the eastern and south-eastern part of the EU have also gained in importance.

\section{The Role of Transport Services in the Polish Economy}

Transport and logistics is one of the key sectors of the Polish economy, with almost $5 \%$ of GDP and employing 400 thousand people. Its importance is determined not only by its own potential, but also by its role in the efficient functioning of the entire economy. The economic growth and, as a result, thriving international trade create excellent prospects for the development of the Polish transport service market in Poland and internationally. The analysis of world trade indicates that the role of Central and Eastern Europe as a location for foreign direct investment is growing.

The role of trade in individual economies can be assessed using the export and import ratios. Due to the nature and scope of the research, the former of these indicators was calculated using revenues made by Poland from international sales of transport services to EU member states and the value of the gross domestic product (GDP). The ratio of the two figures depicts the degree to which the Polish economy is open to foreign markets (in this case the EU markets). Also, the same ratio allows for assessing how much export-oriented the economy is, as basically the higher the ratio the better [52].

In the analysed period, the rate of Polish export of transport services to EU countries was $1.41 \%$ in 2010 and $2.69 \%$ in 2018 (Figure 2). Additionally, its cyclical, annual growth, although with different dynamics, is worth noting. This should be interpreted as a systematically increasing openness of the Polish economy to international trade relations with EU members, in the context of the trade in the transport services under consideration. The growing export rate of the analysed services also results in an improvement in the competitiveness of the national economy. The import rate of transport services calculated for Polish trade relations with EU members increased from $0.97 \%$ in the base year to $1.29 \%$ in the target year. Changes in the share of imports of the analysed services in the Polish GDP were relatively small, therefore it may be assumed that in the examined period the dependence of the Polish economy on imports of transport services from EU markets was slowly and slightly increasing.

The analysed ratios relate to a nine-year period, which leads to the conclusion that the openness of the economy to international trade with European Union countries is of a lasting nature. In addition, the dynamics of the export rate of transport services was higher than the import rate in the entire analysed period of research. Research has shown that the trade in transport services with EU countries is a significant determinant of the development of the Polish economy and provides economic benefits, which is reflected in GDP.

The activity of companies which carry out international transactions is also an important issue in assessing the role of services in foreign trade. It is their economic activity that determines their sales returns. According to the latest data from the Central Statistical Office, $[53,54]$ there were almost 137.4 thousand enterprises which carried out export transactions in 2018 in Poland, 71.3\% of which concluded contracts with partners from the European Union. More than 216.7 thousand business entities were involved in import activities, $76.3 \%$ of which established trade relations within the EU. In the "Transportation and storage services" category, export activities were carried out by more than 8 thousand enterprises, of which more than 3.7 thousand (i.e., 46.2\%) on the EU market. As regards the imports, it was over 14.9 thousand business entities, of which almost 14 thousand (i.e., 93.6\%) operated on the basis of the EU market. According to the data presented, 
approximately three quarters of companies engaged in foreign trade and registered in Poland have carried out transactions within the EU. In the transport sector, this was the vast majority in imports and less than half in exports.

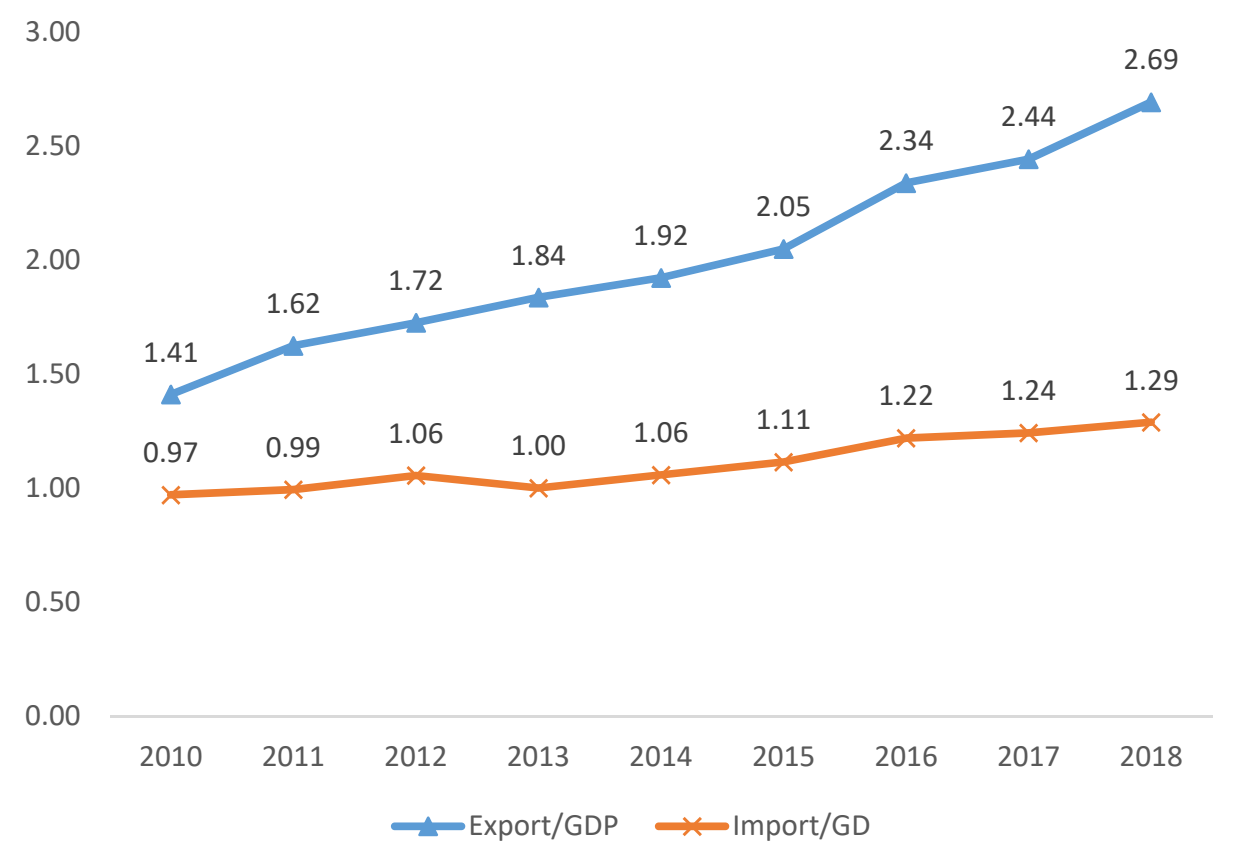

Figure 2. The ratio of exports of transport services to EU member states to the Polish GDP (\%) and the ratio of imports of transport services from EU member states to the Polish GDP (\%). Source: Compiled by the authors based on [51].

International trade transactions carried out as part of Polish foreign trade in services are dominated by joint ventures. This applies to most service categories included in the statistics of the National Bank of Poland [51]. For example, in 2018, only two types of services, provided predominantly by domestic enterprises, were the exception: cultural and recreational services (both in exports and imports) and construction services (in exports). In respect of transport services, joint ventures accounted for $52.2 \%$ of exports and $72.6 \%$ of imports. It should be added that these were the lowest values in comparison with other services, which should be considered a success from the perspective of the national economy. For comparison, the largest share of joint ventures was recorded in the case of exports in financial services $(92.3 \%)$, and in the case of imports in the category of fees for the use of intellectual property $(89.4 \%)$.

Moreover, an interesting indicator reflecting the importance of foreign trade for the country's economy is the ratio of the value of exports and imports to the population. Revenues from the sale of transport services to EU countries increased from EUR 0.13 million per capita in 2010 to EUR 0.35 million per capita in 2018. This was an increase of 177\%. Expenditure on foreign acquisition of transport services increased during the discussed period as well, however to a lesser extent, by 93\% (i.e., from EUR 0.09 million per capita to EUR 0.17 million per capita). As may be observed, the dynamics of the analysed indicators are more favourable for the export of transport services, and the economic benefits of international trade in the services under analysis have increased.

\section{Sustainable Transport as a Factor in the Competitiveness of Polish Transport Companies}

The studies carried out indicate the importance of transport services in Polish foreign trade. It must be noted that in 2018 alone, Polish companies transported almost 270 million tons of freight, representing $23 \%$ of the EU road freight [7]. 
Polish carriers are clearly dominant in bilateral transport between Poland and other EU member states (Figure 3). The share of Polish transport companies in the trade between Poland and other EU member states was nearly 93\% in 2018. 2018 saw the first decline in international transport operations in 15 years. Compared to 2017, the transport operations by Polish companies decreased by $6.4 \%$ considering the volume of freight. This may indicate a declining competitiveness of Polish carriers. One way of improving this competitiveness over the long term should be to implement the principles of sustainable/green transport. They would serve to build sustainable relationships between modes of transport by [55]:

- developing and introducing new fuels and propulsion systems compliant with the principle of sustainable development,

- $\quad$ optimizing the operation of multimodal logistic chains, inter alia by using more energy-efficient means of transport,

- $\quad$ increasing efficiency in the use of transport and infrastructure through information systems and market incentives.

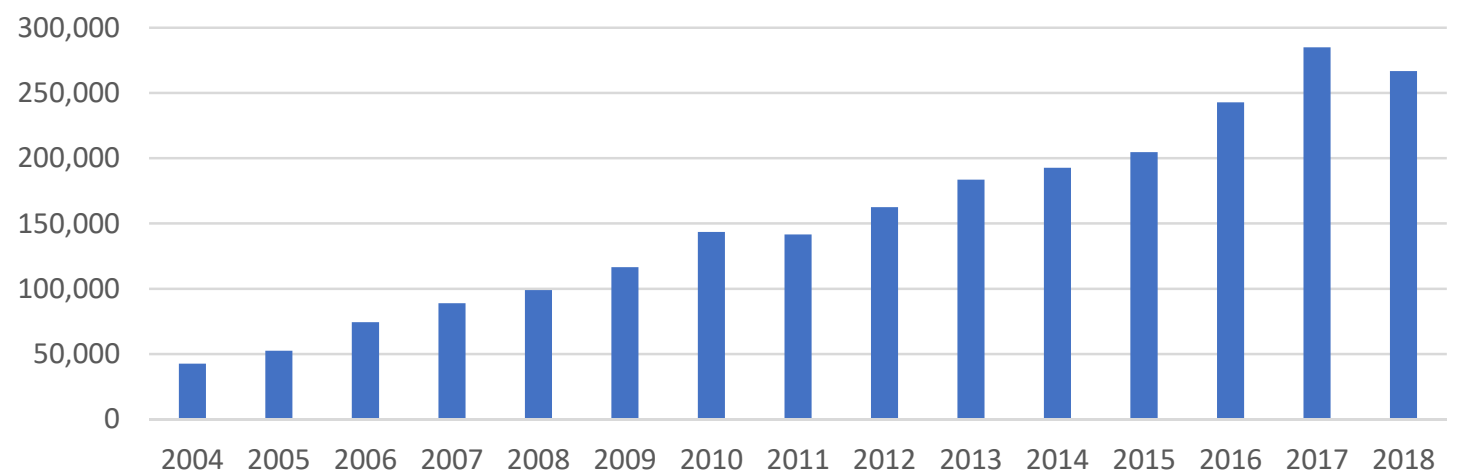

Figure 3. International transport by Polish carriers. Source: Compiled by the authors based on [7].

The ongoing technological developments are transforming transport into a cuttingedge technological sector [56]. Innovation in transport depends on several factors, such as business innovation, regulations, fuel costs and poor performance of the existing solutions. J. Eliasson and S. Proost [57] claim that transport innovation and development are dependent on a sustainable development policy at national and international levels. T.R. Lakshmanam and W.P. Anderson [58] have shown that as technological innovation improves the use of transport products and services becomes more efficient in the transport sector. In order to remain on the market, carriers are forced to innovate in order to achieve the objectives of increased mobility and environmental protection [58]. T. Riley believes that reducing carbon emissions is a major challenge for new technologies in the transport sector. The aim of any actions should therefore be to reduce the dependence of freight transport on fossil fuels and to improve logistics management [59].

The research conducted among 25 Polish transport sector managers showed that $78 \%$ of the respondents intended to implement sustainable development principles over the upcoming five years through the use of low carbon means of transport and biofuels, and through a wider use of transhipment terminals powered by renewable energy. They also pointed out that the implementation of sustainable development principles in how transport companies were run would significantly shape the competitiveness of their services in international transport.

Actions undertaken by individual business owners should also be accompanied by systemic solutions. The concept of an IT platform supporting multimodal transport management may be one embodiment of that approach. The platform should be able to allow the exchange of goods on the road between different carriers and between different fleets. This would reduce the number of unnecessary overlapping runs, which normally has a direct impact on environmental pollution. Such a system should take into account not only the customers' requirements as to service quality, but above all the condition of the vehicle, 
the type of fuel it uses, the working time of a single driver, traffic limitations, etc. The need to roll out this type of solutions is fully compliant with the afore-described concepts of eco-marketing, green transport and CSR. Confirmations of this claim are found in the papers by V. Marchau, W. Walker and R. van Duin [60], who in their analyses of innovative case studies point to the importance of the so-called "relational innovation", novel solutions that are tailored to the needs of individuals or entities. According to the research conducted among Polish transport company managers, $84 \%$ of them believe that the upcoming years will witness an increasing demand for transport services compliant with the green transport concept. According to as many as $92 \%$ of the respondents, the customers' expectation of having the opportunity to make an informed choice of environmentally friendly means of transport is one of the key challenges facing the entire transport industry. The measures taken in this area have so far been very limited.

\section{Conclusions}

Sustainable transport, defined as the right balance between economic, social and environmental values, should become one of the key elements in building the competitiveness of Polish transport companies. As sustainable development policy has increased, the role of the state, which is a key player in pursuing such development, has also changed.

Private owners of transport companies and the state managing the technical infrastructure (roads, ports, railways) play central roles in creating a competitive position for road transport in Poland. The dynamic development of transport services in Poland has so far been made possible mainly by the price competitiveness of Polish transport companies.

Unfortunately, the development of the transport sector has had a very strong impact on society as a whole through increased environmental pollution, noise and traffic congestion, the so-called external costs of transport. Cooperation between authorities and transport sector stakeholders is therefore needed. This will reduce the external costs associated with the development of transport which have a direct impact on the environment.

The research showed that managers in transport companies intend to implement sustainability through the use of low carbon modes of transport and biofuels, and through a wider use of transhipment terminals powered by renewable energy. There is an absolute need of a system to be established that will manage the exchange of goods on the road between different carriers and between different fleets. This would reduce the number of unnecessary overlapping runs, which has a direct impact on environmental pollution. Such a system should take into account not only the customer's requirements as to service quality, but above all the condition of the vehicle, the type of fuel it uses, the working time of a single driver, traffic limitations, etc. This would increase the competitiveness of those carriers that invest in environmentally friendly technologies.

The role of the state should be to create financial/tax incentives to bear the higher costs of purchasing environmentally friendly means of transport. According to the respondents representing the transport industry, air pollutant emissions can be avoided by co-financing undertakings that aim at reducing the use of carbon fuels in transport. Many institutional and legal barriers to the development of sustainable transport must be removed [61]. The state also plays an important role in eliminating transport-related risks to society. It is therefore necessary to build and expand the network of motorways, express roads and ring roads. This will provide an opportunity to create convenient trade routes and improve traffic flow on national roads and international routes. This will also reduce noise and smog caused by transport in urban areas, improve carriage and reduce the external costs of transport on a global scale.

Such state activity may facilitate the implementation of the green transport concept and thus make the expected further development of the transport industry more environmentally friendly. This will contribute to reducing the external environmental costs of transport without adversely affecting international trade.

Further significant development of Polish trade in transport services requires the establishment of an effective and innovative transport and logistics system for Poland and 
the entire European Union. In particular, it is crucial that it meets the requirements for sustainable development. The changing market provides new opportunities, however also poses new challenges for the Polish entities from the transport service sector. Growing expectations of customers and the need to ensure competitive prices require the introduction of new environmentally friendly services and solutions. It seems that entities able to meet these new customer expectations will be able to achieve a strong market position.

Author Contributions: Conceptualisation, A.M. (Agnieszka Malkowska); data curation, A.M. (Agnieszka Malkowska); formal analysis, A.M. (Agnieszka Malkowska) and A.M. (Arkadiusz Malkowski); investigation, A.M. (Agnieszka Malkowska), and A.M. (Arkadiusz Malkowski).; methodology, A.M. (Agnieszka Malkowska) and A.M. (Arkadiusz Malkowski); resources, A.M. (Arkadiusz Malkowski); writing-original draft, A.M. (Agnieszka Malkowska), and A.M. (Arkadiusz Malkowski); writing-review and editing, A.M. (Agnieszka Malkowska), and A.M. (Arkadiusz Malkowski) All authors have read and agreed to the published version of the manuscript.

Funding: The project is financed within the framework of the program of the Minister of Science and Higher Education under the name "Regional Excellence Initiative" in the years 2019-2022; project number 001/RID/2018/19. The amount of financing: PLN 10,684,000.00.

Institutional Review Board Statement: Not applicable.

Informed Consent Statement: Not applicable.

Acknowledgments: We would like to thank all the reviewers and the journal editors for their insightful comments and suggestions towards improving our manuscript.

Conflicts of Interest: The authors declare no conflict of interest.

\section{References}

1. Siche, J.R.; Agostinho, F.; Ortega, E.; Romeiro, A. Sustainability of Nations by Indices: Comparative Study between Environmental Sustainability Index, Ecological Footprint and the Emergy Performance Indices. Ecol. Econ. 2008, 66, 628-637. [CrossRef]

2. Abaza, H.; Hamwey, R. Integrated Assessment as a Tool for Achieving Sustainable Trade Policies. Environ. Impact Assess. Rev. 2001, 21, 481-510. [CrossRef]

3. Bossel, H. Indicators for Sustainable Development: Theory, Method, Applications; International Institute for Sustainable Development: Winnipeg, MB, Canada, 1999.

4. Kjosevski, S.; Kochov, A.; Kostikj, A.; Danev, D. Trafic Indicators in Context of Sustainable Transport Development. Mach. Technol. Mater. 2018, 12, 175-177.

5. Bas, M. Does Services Liberalization Affect Manufacturing Firms' Export Performance? Evidence from India. J. Comp. Econ. 2014, 42, 569-589. [CrossRef]

6. Krugman, P.; Melitz, M.; Obstfeld, M. International Economics: Theory and Policy, Global Edition; Pearson: Hoboken, NJ, USA, 2012.

7. Road Freight Transport Measurement. Available online: Https://Appsso.Eurostat.Ec.Europa.Eu/Nui/Show.Do?Dataset=road_ go_ta_tott\&lang=en (accessed on 1 November 2020).

8. Drela, K.; Malkowska, A.; Zieziula, J. Handel Zagraniczny Obroty Towarowe i Ustugowe Polski w Ujęciu Regionalnym. Wybrane Zgadnienia, 1st ed.; Wydawnictwo Naukowe Uniwersytetu Szczecińskiego: Szczecin, Poland, 2019.

9. Prause, G. Sustainable Development of Logistics Clusters in Green Transport Corridors. J. Secur. Sustain. Issues 2014, 4. [CrossRef]

10. McKinnon, A.; Browne, M.; Whiteing, A.; Piecyk, M. Green Logistics: Improving the Environmental Sustainability of Logistics; Kogan Page Publishers: London, UK, 2015.

11. Ritzer, G.; Dean, P. Globalization: A Basic Text, 2nd ed.; Wiley-Blackwell: Chichester, UK; West Sussex, UK; Malden, MA, USA, 2015.

12. Rowntree, L.; Lewis, M.; Price, M.; Wyckoff, W. Globalization and Diversity: Geography of a Changing World, 5th ed.; Pearson: Hoboken, NJ, USA, 2016.

13. Harsch, B. Consumerism and Environmental Policy: Moving Past Consumer Culture. Ecol. Law Q. 1999, 26, 543-610.

14. Ritzer, G.; Malone, E.L. Globalization Theory: Lessons from the Exportation of McDonaldization and the New Means of Consumption. Am. Stud. 2000, 41, 97-118.

15. Atkinson, A.B.; Micklewright, J.; Micklewright, M. Economic Transformation in Eastern Europe and the Distribution of Income; Cambridge University Press: Cambridge, UK, 1992.

16. Lavoie, M. Post-Keynesian Economics: New Foundations; Edward Elgar Publishing: Cheltenham, UK, 2014.

17. Meardi, G.; Marginson, P.; Fichter, M.; Frybes, M.; Stanojević, M.; Tóth, A. The Complexity of Relocation and the Diversity of Trade Union Responses: Efficiency-Oriented Foreign Direct Investment in Central Europe. Eur. J. Ind. Relat. 2009, 15, 27-47. [CrossRef] 
18. Baldwin, R. The Potential for Trade between the Countries of EFTA and Central and Eastern Europe; CEPR Discussion Papers: London, UK, 1993.

19. Head, K.; Mayer, T.; Ries, J. How Remote Is the Offshoring Threat? Eur. Econ. Rev. 2009, 53, 429-444. [CrossRef]

20. Roza, M.; Van den Bosch, F.A.; Volberda, H.W. Offshoring Strategy: Motives, Functions, Locations, and Governance Modes of Small, Medium-Sized and Large Firms. Int. Bus. Rev. 2011, 20, 314-323. [CrossRef]

21. Gnangnon, S.K. Manufacturing Exports and Services Export Diversification. Int. Trade J. 2020, 1-22. [CrossRef]

22. Hoekman, B.; Mattoo, A.; Sapir, A. The Political Economy of Services Trade Liberalization: A Case for International Regulatory Cooperation? Oxf. Rev. Econ. Policy 2007, 23, 367-391. [CrossRef]

23. Kimura, F.; Lee, H.-H. The Gravity Equation in International Trade in Services. Rev. World Econ. 2006, 142, 92-121. [CrossRef]

24. Rubalcaba, L. Business Services in European Economic Growth. Strateg. Dir. 2012. [CrossRef]

25. Zahler, A.; Iacovone, L.; Mattoo, A. Trade and Innovation in Services: Evidence from a Developing Economy. World Econ. 2014, 37, 953-979. [CrossRef]

26. Esmer, Y. Globalization, “McDonaldization” and Values: Quo Vadis? Comp. Sociol. 2006, 5, 183-202. [CrossRef]

27. Petro, F.; Konečnỳ, V. Calculation of Emissions from Transport Services and Their Use for the Internalisation of External Costs in Road Transport. Procedia Eng. 2017, 192, 677-682. [CrossRef]

28. Maibach, M.; Schreyer, C.; Sutter, D.; Van Essen, H.P.; Boon, B.H.; Smokers, R.; Schroten, A.; Doll, C.; Pawlowska, B.; Bak, M. Handbook on Estimation of External Costs in the Transport Sector; CE Delft: Delft, The Netherlands, 2008; 336p.

29. Ribau, J.P.; Silva, C.M.; Sousa, J.M. Efficiency, Cost and Life Cycle $\mathrm{CO}_{2}$ Optimization of Fuel Cell Hybrid and Plug-in Hybrid Urban Buses. Appl. Energy 2014, 129, 320-335. [CrossRef]

30. Hansen, U. Reverse Logistics Is the Key for Remanufacturing and a Sustainable Development. In Proceedings of the 2000 IEEE International Symposium on Electronics and the Environment (Cat. No. 00CH37082), San Francisco, CA, USA, 10 May 2000; pp. 238-242.

31. Czumałmiołczyk, L. Analysis of the Use of Alternative Fuels in Public Transport in the Context of Sustainable Management. World Sci. News 2019, 125, 193-203.

32. Tolley, R. Sustainable Transport; Elsevier: Amsterdam, The Netherlands, 2003.

33. Van den Bergh, J.C.; Nijkamp, P. Aggregate Dynamic Economic-Ecological Models for Sustainable Development. Environ. Plan. A 1991, 23, 1409-1428. [CrossRef]

34. Van Veen-Groot, D.B.; Nijkamp, P. Globalisation, Transport and the Environment: New Perspectives for Ecological Economics. Ecol. Econ. 1999, 31, 331-346. [CrossRef]

35. Banister, D.; Akerman, J.; Nijkamp, P.; Stead, D.; Dreborg, K.; Steen, P.; Schleicher-Tappeser, R. European Transport Policy and Sustainable Mobility; Taylor \& Francis: Milton Park, UK, 2000.

36. Gudmundsson, H.; Wyatt, A.; Gordon, L. Benchmarking and Sustainable Transport Policy: Learning from the BEST Network. Transp. Rev. 2005, 25, 669-690. [CrossRef]

37. McDaniel, S.W.; Rylander, D.H. Strategic Green Marketing. J. Consum. Mark. 1993, 10, 4-10. [CrossRef]

38. Ottman, J.; Books, N.B. Green Marketing: Opportunity for Innovation. J. Sustain. Prod. Des. 1998, 60, $136-667$.

39. Polonsky, M.J.; Rosenberger III, P.J. Reevaluating Green Marketing: A Strategic Approach. Bus. Horiz. 2001, 44, 21-30. [CrossRef]

40. Aditjandra, P.T.; Zunder, T.H.; Islam, D.M.Z.; Palacin, R. Green Rail Transportation: Improving Rail Freight to Support Green Corridors. In Green Transportation Logistics; Springer: Berlin/Heidelberg, Germany, 2016; pp. 413-454.

41. Ilieva, G.; Pascoa, J.; Dumas, A.; Trancossi, M. MAAT-Promising Innovative Design and Green Propulsive Concept for Future Airship's Transport. Aerosp. Sci. Technol. 2014, 35, 1-14. [CrossRef]

42. Schröder, M.; Prause, G. Transportation of Dangerous Goods in Green Transport Corridors-Conclusions from Baltic Sea Region. Transp. Telecommun. J. 2016, 17, 322-334. [CrossRef]

43. Tsakalidis, A.; van Balen, M.; Gkoumas, K.; Pekar, F. Catalyzing Sustainable Transport Innovation through Policy Support and Monitoring: The Case of TRIMIS and the European Green Deal. Sustainability 2020, 12, 3171. [CrossRef]

44. Turoń, K.; Golba, D.; Czech, P. The Analysis of Progress CSR Good Practices Areas in Logistic Companies Based on Reports "Responsible Business in Poland. Good Practices" in 2010-2014. Sci. J. Sil. Univ. Technol. Ser. Transp. 2015, 89, $163-171$.

45. Zhao, X.; Ke, Y.; Zuo, J.; Xiong, W.; Wu, P. Evaluation of Sustainable Transport Research in 2000-2019. J. Clean. Prod. 2020, 256. [CrossRef]

46. Skorobogatova, O.; Kuzmina-Merlino, I. Transport Infrastructure Development Performance. Procedia Eng. 2017, 178, 319-329. [CrossRef]

47. Ali, Y.; Socci, C.; Pretaroli, R.; Severini, F. Economic and Environmental Impact of Transport Sector on Europe Economy. Asia Pac. J. Reg. Sci. 2018, 2, 361-397. [CrossRef]

48. Hartley, J. Case Study Research. In Essential Guide to Qualitative Methods in Organizational Research; Cassell, C., Symon, G., Eds.; Sage Publications Ltd.: London, UK, 2004; pp. 323-333.

49. Yin, R.K. Case Study Research: Design and Methods, 3rd ed.; Sage Publications: Thousand Oaks, CA, USA, 2003.

50. Fann, K.T. Peirce's Theory of Abduction; Springer Science \& Business Media: Berlin/Heidelberg, Germany, 2012.

51. National Bank of Poland, Międzynarodowy Handel Usługami Polski w 2018 Roku. Available online: https://www.nbp.pl/home. aspx?f=/statystyka/mhu.html (accessed on 21 December 2020). 
52. Malkowska, A. Polish-German Trade in Innovative and Knowledge-Based Services in 2010-2017. In Proceedings of the 19th International Joint Conference: Central and Eastern Europe in the Changing Business Environment, Prague, Czech Republic, 24 May 2019; p. 195.

53. Statistics Poland, Yearbook Trade of Foreign Statistics of Poland, Warsaw. 2019. Available online: https://stat.gov.pl/en/ topics/statistical-yearbooks/statistical-yearbooks/yearbook-of-foreign-trade-statistics-of-poland-2019,9,13.html (accessed on 12 December 2020).

54. Statistics Poland, Yearbook Trade of Foreign Statistics of Poland, Warsaw. 2011. Available online: https://stat.gov.pl/obszarytematyczne/roczniki-statystyczne/roczniki-statystyczne/rocznik-statystyczny-przemyslu-2011-wybrane-tablice,5,5.html? contrast=default (accessed on 6 December 2020).

55. WHITE PAPER Roadmap to a Single European Transport Area-Towards a Competitive and Resource Efficient Transport System, European Commission, EN EN EUROPEAN COMMISSION Brussels, 28.3.2011 COM(2011) 144 Final. Available online: https: / / eur-lex.europa.eu/lexuriserv/lexuriserv.do?uri=com:2011:0144:fin:en:pdf (accessed on 11 December 2020).

56. Goldman, T.; Gorham, R. Sustainable Urban Transport: Four Innovative Directions. Technol. Soc. 2006, 28, 261-273. [CrossRef]

57. Eliasson, J.; Proost, S. Is Sustainable Transport Policy Sustainable? Transp. Policy 2015, 37, 92-100. [CrossRef]

58. Lakshmanam, T.R.; Anderson, W.P. Transportation in the Twenty-First Century Technological Innovation, in: Transportation Engineering and Planning. Available online: https:/ / www.eolss.net/sample-chapters/c05/e6-40-03-06.pdf (accessed on 22 December 2020).

59. Ryley, T.; Elmirghani, J.; Budd, T.; Miyoshi, C.; Mason, K.; Moxon, R.; Ahmed, I.; Qazi, B.; Zanni, A. Sustainable Development and Airport Surface Access: The Role of Technological Innovation and Behavioral Change. Sustainability 2013, 5, 1617-1631. [CrossRef]

60. Marchau, V.; Walker, W.; Van Duin, R. An Adaptive Approach to Implementing Innovative Urban Transport Solutions. Transp. Policy 2008, 15, 405-412. [CrossRef]

61. Curtis, C.; Low, N. Institutional Barriers to Sustainable Transport; Routledge: Abingdon, UK, 2016. 